\title{
Enhancement of sperm transport through the rat epididymis after castration*
}

\author{
S. Sujarit and C. Pholpramool \\ Department of Physiology, Faculty of Science, Mahidol University, Rama VI Road, Bangkok 10400, \\ Thailand
}

\begin{abstract}
Summary. Transport of spermatozoa through different regions of the epididymis has been followed by labelling testicular spermatozoa with $\left[{ }^{3} \mathrm{H}\right]$ thymidine in intact rats and in rats in which the efferent ducts were ligated or the testes were removed. In intact rats, the transit times of epididymal spermatozoa from the initial segment to the caput, from the caput to the corpus, and from the corpus to the cauda were 2,4 and 2 days, respectively, giving a total transit time of 8 days. After bilateral castration, labelled spermatozoa were transferred from the initial segment into the proximal cauda by 2 days and appeared in the ductus deferens by 4 days. This effect was prevented by a daily subcutaneous injection of testosterone propionate $(0 \cdot 2 \mathrm{mg} / \mathrm{kg})$. Bilateral efferent duct ligation had only a slight effect on the passage of epididymal spermatozoa. The results indicate that epididymal sperm transport is enhanced after androgen withdrawal.
\end{abstract}

\section{Introduction}

The acquisition by spermatozoa of motility and the ability to fertilize eggs during their transit through the epididymis is androgen dependent (for review see Orgebin-Crist, Danzo \& Davies, 1975). The hormonal regulation of sperm transport through the epididymis is still unclear although measurements of epididymal sperm reserves after castration in the rat (Dyson \& Orgebin-Crist, 1973; Pholpramool, White \& Setchell, 1982) and the hamster (Lubicz-Nawrocki, 1974) or after oestrogen treatment in the mouse (Meistrich, Hughes \& Bruce, 1975) suggest that epididymal sperm transport is enhanced by androgen deprivation. It has been reported that spontaneous contractions of the epididymis are stimulated by testosterone because motility of the rat epididymal duct ceased shortly after castration (Risley, 1963; Hib \& Ponzio, 1977). However, DinUdom, Sujarit \& Pholpramool (1985) measured intraluminal pressure in the rat epididymis and showed that spontaneous contractions of all regions were maintained for 5 days after castration or for 21 days during cyproterone acetate treatment. Furthermore, there appeared to be an increase, not a decrease, in contractility of the epididymal duct after androgen deprivation since the amplitude of contraction was elevated. In the present study, we have reinvestigated the role of androgens on the passage through the rat epididymis of spermatozoa labelled with $\left[{ }^{3} \mathrm{H}\right]$ thymidine.

\section{Materials and Methods}

Sexually mature, Fischer albino rats of the Mahidol University colony, weighing 240-270 $\mathrm{g}$ were housed in groups of 8-10 animals separated from females. Lighting conditions were constant ( $12 \mathrm{~h}$ light $/ 24 \mathrm{~h}$ ) and there was free access to food and water.

* Reprint requests to Dr C. Pholpramool. 


\section{Experimental procedure}

Normal rats. The animals were randomly assigned to 11 groups of 5-12 rats. The testicular spermatozoa were labelled using $\left[{ }^{3} \mathrm{H}\right]$ thymidine as previously described by others (KoefoedJohnsen, 1960; Amann, Koefoed-Johnsen \& Levi, 1965; Orgebin-Crist, 1965; Meistrich et al., 1975) except that the isotope was injected into the testis. Briefly, after light ether anaesthesia, all rats received single injections of $15 \mu \mathrm{Ci}\left[{ }^{3} \mathrm{H}\right]$ thymidine ([methyl- $\left.{ }^{3} \mathrm{H}\right]$ thymidine, sp. act. 25 $\mathrm{Ci} / \mathrm{mmol}$; Amersham International plc, U.K.), dissolved in $0.2 \mathrm{ml} 0.9 \%$ (w/v) sodium chloride solution, into both testes. The rats were then returned to their cages and kept for 35-52 days. On Days $35,38,40,42,43,44,46,48,49,50$ and 52 rats were killed by an overdose of ether. Both testes and epididymides were removed and freed of fat. The testicular capsule was opened and separated from the parenchyma. The latter was weighed and then forced through a needle (21-gauge) into a test tube containing $5 \mathrm{ml} 0.9 \% \mathrm{NaCl}$. The epididymides were cut into 5 segments, i.e. the initial segment, the caput, the corpus, the proximal cauda and the distal cauda, as described by Hinton, Dott \& Setchell (1979). The corresponding segments from each epididymis of an animal were combined and weighed, and then macerated with clean scissors. The tissue fragments were suspended in 5-8 $\mathrm{ml} 0.9 \% \mathrm{NaCl}$ with gentle shaking for a few minutes. The suspension was allowed to settle for 40-60 min and the suspension was then aspirated using a clean Pasteur pipette and transferred into a centrifuge tube. After appropriate dilution with $0.9 \% \mathrm{NaCl}$, a small volume (10$20 \mu \mathrm{l})$ of the suspension was removed for sperm counting in a haemocytometer. The spermatozoa and any other cellular debris were counted in duplicate samples. Contamination with other cells or cellular debris was usually $<10 \%$ in the epididymal homogenates. The remaining sperm suspension was centrifuged in a bench-type clinical centrifuge for $30 \mathrm{~min}$. The precipitate was dissolved in 0.5 $\mathrm{ml} \mathrm{2 \%}$ SDS (sodium dodecyl sulphate) and $0.5 \mathrm{ml} 26 \mathrm{~mm}$-DTT ((-)-1,4-dithio-l-threitol; Sigma, Missouri, U.S.A.) at room temperature for $2 \mathrm{~h}$ and kept overnight in a refrigerator.

The solubilized spermatozoa were diluted with $10 \mathrm{ml}$ scintillation liquid (toluene: Triton $\mathrm{X}$ $100,2: 1 \mathrm{v} / \mathrm{v}$, containing $4.0 \mathrm{~g}$ PPO and $0 \cdot 1 \mathrm{~g}$ POPOP per litre) and the radioactivity was determined in a liquid scintillation counter (LS-3133T, Beckman, U.S.A.).

In some experiments $3-4 \mathrm{~cm}$ portions of the ductus deferens were also collected and similarly treated as described above. Intratesticular injection of $\left[{ }^{3} \mathrm{H}\right]$ thymidine had no effect on the sperm production since the total sperm counts in the epididymides of untreated rats and rats receiving isotope injection were similar. Sperm counts (mean \pm s.e.m.) in the initial segment, caput, corpus, proximal cauda and distal cauda epididymidis of 5 untreated rats were, respectively, $42 \pm 6,68 \pm$ $6,68 \pm 10,115 \pm 16$ and $150 \pm 13 \times 10^{6}$ spermatozoa/g tissue; the corresponding values in 6 rats injected with $\left[{ }^{3} \mathrm{H}\right]$ thymidine were $32 \pm 4,74 \pm 7,63 \pm 13,114 \pm 12$ and $164 \pm 23 \times 10^{6}$ spermatozoa/g tissue.

Treatment groups. Preliminary experiments in normal rats showed that the majority of labelled spermatozoa appeared in the initial segment and the caput epididymidis on Days 38 and 40 after isotope injection, respectively. On Day 38 after injection of $\left[{ }^{3} \mathbf{H}\right]$ thymidine, rats were anaesthetized with ether and a mid-line abdominal incision was made. The testes and the epididymides were gently exposed through the incision and the efferent ducts were bilaterally ligated. Both testes were either removed (bilateral castration) or left intact (bilateral efferent duct ligation). The epididymides with or without testes were then returned to the scrotal sac and the incision was closed. Other groups of rats, which served as controls, were sham-operated or bilaterally castrated but received subcutaneous injections $(0.2 \mathrm{ml})$ of testosterone propionate (Nutrition Biochemicals, Ohio, U.S.A.) in corn oil at a dose of $0.2 \mathrm{mg} / \mathrm{kg}$ per day. The animals were allowed to recover and kept for 2 or 4 days. They were killed by ether anaesthesia on Days 40 and 42 , and the testes and the epididymides were removed and processed as described above.

\section{Analysis of data}

Since numbers of spermatozoa were unequal in control and treatment groups, data are presented as a percentage of the total radioactivity (c.p.m.) recovered in the whole epididymis per 
$10^{6}$ spermatozoa. Differences between control and treatment groups were determined using analysis of variance. A $P$ value of $<0.05$ was considered to be statistically significantly different.

\section{Results}

Transit time in different regions of the epididymis

By 35 days after administration of $\left[{ }^{3} \mathrm{H}\right]$ thymidine, $97 \pm 1 \%$ (mean \pm s.e.m., $n=5$ ) of the total radioactivity still remained in the testis. However, by Day 38 a substantial number of labelled spermatozoa appeared in the epididymis. The level of radioactivity was highest in the initial segment accounting for $63 \%$ of the total radioactivity in the epididymis (Table 1). By Day 40 , the peak of labelled spermatozoa had moved into the caput and remained in this region for 2 days. The mass of labelled spermatozoa had reached the corpus by Days 43 and 44 . From Days 46 to 52 most of the labelled spermatozoa were in the cauda epididymidis (Table 1). The estimated transit time (calculated from the time difference between peaks of radioactivity in two adjacent regions) from the initial segment to the caput, from the caput to the corpus, and from the corpus to the proximal cauda were 2, 4 and 2 days, respectively. Since approximately equal numbers of labelled spermatozoa reached the proximal and distal cauda on Day 46, the transit time for the proximal cauda was less than 1 day and the total transit time from the initial segment to the distal cauda epididymidis was about 8 days, i.e. from Days 38 to 46 , after injection of the thymidine into the testis (Table 1).

\section{Effect of bilateral efferent duct ligation}

There was a slight effect on the passage of spermatozoa further along the epididymal duct if fluid flow from the testis was blocked by ligation of the efferent ducts on Day 38, by which time most of the labelled spermatozoa were in the initial segment (Table 1). On Day 40, the peak of labelled spermatozoa was in the caput as in the normal or sham-operated rats (Table 2). However, labelled spermatozoa had moved into the corpus on Day 42, which was 1 day faster than for normal or sham-operated rats.

\section{Effect of bilateral castration}

The transport of labelled spermatozoa through all regions of the epididymis was enhanced in castrated rats. By 2 days after castration performed on Day 38 after the intratesticular injection of

Table 1. Percentage distribution of labelled spermatozoa in different regions of the rat epididymis after intratesticular injection of $\left[{ }^{3} \mathrm{H}\right]$ thymidine

\begin{tabular}{ccccccc}
\hline & \multicolumn{5}{c}{$\%$ c.p.m./106 epididymal spermatozoa in: } \\
\cline { 2 - 7 } $\begin{array}{c}\text { Days after } \\
\text { [3H]thymidine }\end{array}$ & $\begin{array}{c}\text { No. of } \\
\text { rats }\end{array}$ & $\begin{array}{c}\text { Initial } \\
\text { segment }\end{array}$ & Caput & Corpus & $\begin{array}{c}\text { Proximal } \\
\text { cauda }\end{array}$ & $\begin{array}{c}\text { Distal } \\
\text { cauda }\end{array}$ \\
\hline 35 & 5 & $1 \pm 0 \cdot 5$ & $0 \cdot 3 \pm 0 \cdot 1$ & $0 \cdot 4 \pm 0 \cdot 1$ & $0 \cdot 3 \pm 0 \cdot 1$ & $0 \cdot 6 \pm 0 \cdot 4$ \\
38 & 10 & $63 \pm 10$ & $22 \pm 8$ & $10 \pm 6$ & $4 \pm 2$ & $2 \pm 1$ \\
40 & 6 & $24 \pm 9$ & $73 \pm 9$ & $2 \pm 0 \cdot 4$ & $0 \cdot 4 \pm 0 \cdot 1$ & $0 \cdot 4 \pm 0 \cdot 1$ \\
42 & 12 & $12 \pm 2$ & $67 \pm 5$ & $20 \pm 6$ & $0 \cdot 2 \pm 0 \cdot 05$ & $0 \cdot 1 \pm 0 \cdot 04$ \\
43 & 9 & $11 \pm 2$ & $27 \pm 8$ & $61 \pm 8$ & $2 \pm 1$ & $0 \cdot 4 \pm 0 \cdot 1$ \\
44 & 6 & $21 \pm 2$ & $8 \pm 1$ & $70 \pm 2$ & $2 \pm 1$ & $0 \cdot 2 \pm 0 \cdot 03$ \\
46 & 5 & $11 \pm 1$ & $12 \pm 2$ & $13 \pm 2$ & $32 \pm 7$ & $32 \pm 9$ \\
48 & 6 & $9 \pm 2$ & $16 \pm 3$ & $25 \pm 2$ & $25 \pm 5$ & $26 \pm 6$ \\
49 & 7 & $8 \pm 0 \cdot 5$ & $26 \pm 9$ & $22 \pm 4$ & $19 \pm 2$ & $25 \pm 7$ \\
50 & 6 & $5 \pm 1$ & $10 \pm 1$ & $38 \pm 6$ & $15 \pm 3$ & $29 \pm 7$ \\
52 & 6 & $4 \pm 1$ & $7 \pm 1$ & $21 \pm 4$ & $36 \pm 4$ & $32 \pm 6$ \\
\hline
\end{tabular}


Table 2. Effects of bilateral efferent duct ligation (EDL), bilateral castration and bilateral castration + testosterone propionate (TP, $0.2 \mathrm{mg} / \mathrm{kg}$ per day) on Day 38 after intratesticular injection of $\left[{ }^{3} \mathrm{H}\right]$ thymidine on the transport of labelled spermatozoa through different regions of the rat epididymis

\begin{tabular}{lcccccccc}
\hline $\begin{array}{c}\text { Treatment } \\
\text { on } \\
\text { Day 38 }\end{array}$ & $\begin{array}{c}\text { No. of } \\
\text { rats }\end{array}$ & $\begin{array}{c}\text { Days after } \\
{\left[{ }^{3} \mathbf{H}\right]-} \\
\text { thymidine }\end{array}$ & $\begin{array}{c}\text { Initial } \\
\text { segment }\end{array}$ & Caput & Corpus & $\begin{array}{c}\text { Proximal } \\
\text { cauda }\end{array}$ & $\begin{array}{c}\text { Distal } \\
\text { cauda }\end{array}$ & $\begin{array}{c}\text { Vas } \\
\text { deferens }\end{array}$ \\
\hline $\begin{array}{l}\text { Sham } \\
\text { operation }\end{array}$ & 5 & 40 & $42 \pm 3$ & $53 \pm 3$ & $3 \pm 1$ & $1 \pm 0 \cdot 1$ & $1 \pm 0 \cdot 2$ & - \\
& 5 & 42 & $44 \pm 2$ & $53 \pm 2$ & $2 \pm 1$ & $1 \pm 0 \cdot 2$ & $1 \pm 0 \cdot 2$ & - \\
EDL & 5 & 40 & $0^{*}+\dagger$ & $87 \pm 4^{*}$ & $9 \pm 3$ & $3 \pm 1 \dagger$ & $2 \pm 0 \cdot 5 \dagger$ & - \\
& 7 & 42 & $0^{* *}$ & $31 \pm 10 \dagger$ & $51 \pm 11^{* *} \dagger \dagger 11 \pm 8$ & $7 \pm 5 \dagger$ & - \\
Castration & 11 & 40 & $10 \pm 7^{* *}$ & $21 \pm 9^{*}$ & $23 \pm 7^{*}$ & $32 \pm 19^{*}$ & $10 \pm 2^{*}$ & $9 \pm 8$ \\
Castration & 4 & 42 & $0^{* *}$ & $0^{* *}$ & $0^{*}$ & $40 \pm 15^{*}$ & $35 \pm 10^{* *}$ & $25 \pm 7$ \\
+ TP & 7 & 40 & $20 \pm 8$ & $63 \pm 13 \dagger$ & $14 \pm 13$ & $1 \pm 0 \cdot 2 \dagger$ & $1 \pm 0 \cdot 2 \dagger \dagger$ & $1 \pm 0 \cdot 4 \dagger$ \\
\hline
\end{tabular}

Values are mean \pm s.e.m.

Compared to the corresponding sham control, ${ }^{*} P<0.05 ;{ }^{* *} P<0.01$.

Compared to the corresponding castration group, $\dagger P<0.05 ; \dagger \uparrow P<0.01$.

thymidine, the peak of radioactivity appeared in the proximal cauda on Day 40 and substantial radioactivity was recovered from the ductus deferens on Day 42 (Table 2).

\section{Effect of bilateral castration and testosterone propionate}

The enhancement of sperm transport which occurred in castrated rats was prevented by administration of testosterone propionate at a dose of $0.2 \mathrm{mg} / \mathrm{kg}$ per day. Most of the labelled spermatozoa were still in the caput on Day 40 (Table 2).

\section{Discussion}

The transport of spermatozoa through the epididymal duct has been studied in many species by different methods (Orgebin-Crist, 1965). The isotope labelling method, however, seems to give more consistent and reliable results (Orgebin-Crist, 1962). This method has been used for the mouse (Meistrich et al., 1975), bull (Koefoed-Johnsen, 1960) and rabbit (Amann et al., 1965; OrgebinCrist, 1965). The total passage times of spermatozoa through the rat epididymis obtained in the present study ( 8 days) are comparable to those estimated from the injection of radio-opaque material into the efferent ducts (7-8 days: Macmillan \& Aukland, 1960) or calculated from the daily sperm reserve ( 8.4 days: Robb, Amann \& Killian, 1978). These values are, however, much higher than that derived from the injection of oil droplets into the epididymal lumen (5.3 days: Jaakkola, 1983). The latter probably does not represent the true value since it was extrapolated from the speed of oil droplets traversed in different regions of the epididymis over a short period $(2 \mathrm{~h})$. The regional transit times derived from this study are also in good agreement with those estimated from radioopaque (Macmillan \& Aukland, 1960) or dye (English \& Dym, 1982) injection studies. However, passage of spermatozoa in the proximal region (the caput and the corpus) was somewhat faster whilst that in the distal region was slower than the values that were calculated from the sperm reserves. The apparently rapid transport of labelled spermatozoa through the proximal cauda (within 1 day) in the present study might have been due to rapid mixing of the luminal contents in the proximal and distal cauda. The epididymal tubule in this region contracts spontaneously and with high amplitude (Hib \& Ponzio, 1977; Markkula-Viitanen, Nikkanen \& Talo, 1979; Pholpramool, Triphrom \& Din-Udom, 1984). Each contraction usually propelled the luminal 
content forward or backward for a considerable distance (unpublished observations). Mixing of labelled spermatozoa and a reflux of luminal fluid content in the cauda epididymidis of rabbits have been observed (Orgebin-Crist, 1965; Prins \& Zaneveld, 1980). The rapid mixing of spermatozoa in the cauda may also explain the constancy of labelled spermatozoa in this region for several days.

The enhancement of passage of labelled spermatozoa through the epididymis by castration supports previous results (Dyson \& Orgebin-Crist, 1973; Lubicz-Nawrocki, 1974; Pholpramool et al., 1982). The increase in the rate of transport occurred as a result of androgen withdrawal since the sperm transport was restored to normal when testosterone was administered to the castrated rats. Ligation of the efferent ducts had only a slight effect. This effect was not due to changes in blood testosterone concentrations which remain normal for 21 days after efferent duct ligation (Main, Davies \& Setchell, 1978). It is likely that a diminution of spermatocrit in the caput and the corpus by 5 days after this operation (Pholpramool et al., 1982) causes a decrease in the viscosity of the luminal content in those regions, thus accelerating fluid movement along the epididymal duct.

The mechanism by which passage of spermatozoa is increased shortly after castration is unclear at present. There are, however, at least three possible explanations for this phenomenon. Firstly, spermatozoa are forced to move forward simply by a reduction in luminal diameter of the epididymal duct. A significant decrease in luminal diameter in the caput and the corpus occurred by 3 days after castration (unpublished observations). Secondly, a decrease in the viscosity of luminal content would facilitate flow of fluid through the epididymal duct. It has been shown that fluid absorption in the epididymis is inhibited after castration (Wong, Au \& Ngai, 1978). A reduction in spermatocrit shortly after androgen withdrawal has also been reported (Pholpramool et al., 1982). Evidence from these studies indicates that the viscosity of the luminal content of the rat epididymis may be decreased by castration. Finally enhancement of sperm transport may be induced by an increase in tubular contractility (Din-Udom et al., 1985). The hypothesis that, in normal male rats, androgens depress the contractions of the epididymal duct to ensure optimal rates of sperm transport in different regions of the epididymis is supported by the present and previous (Din-Udom et al., 1985) results showing that tubular contractions and rates of sperm transport are increased after androgen withdrawal.

We thank Professor B. P. Setchell for valuable comments and criticism on this work; Dr M. K. Holland for reading the manuscript and Miss S. Suter for its preparation.

\section{References}

Amann, R.P., Koefoed-Johnsen, H.H. \& Levi, H. (1965) Excretion pattern of labelled spermatozoa and the timing of spermatozoa formation and epididymal transit in rabbits injected with thymidine ${ }^{3} \mathrm{H} . J$. Reprod. Fert. 10, 169-185.

Din-Udom, A., Sujarit, S. \& Pholpramool, C. (1985) Short-term effect of androgen deprivation on intraluminal pressure and contractility of the rat epididymis. J. Reprod. Fert. 73, 405-410.

Dyson, A.L.M.B. \& Orgebin-Crist, M.C. (1973) Effect of hypophysectomy, castration and androgen replacement upon the fertilizing ability of rat epididymal spermatozoa. Endocrinology 93, 391-402.

English, H.F. \& Dym, M. (1982) The time required for materials injected into the rete testis to reach points in the caput epididymis of the rat and observations on the absorption of cationic ferritin. Ann. N. Y. Acad. Sci. 383, $445-446$

Hib. J. \& Ponzio, R.O. (1977) Effect of efferent duct ligation, gonadectomy and testosterone replacement on epididymal contractility in the rat. J. Reprod. Fert. 50, 327-329.

Hinton, B.T., Dott, H.M. \& Setchell, B.P. (1979) Measurement of the motility of rat spermatozoa collected by micropuncture from the testes and from different regions along the epididymis. $J$. Reprod. Fert. 55, 167-172.

Jaakkola, U.-M. (1983) Regional variations in transport of the luminal contents of the rat epididymis in vivo. J. Reprod. Fert. 68, 465-470.

Koefoed-Johnsen, H.H. (1960) Influence of ejaculation frequency on the time required for sperm formation and epididymal passage in the bull. Nature, Lond. 185, $49-50$.

Lubicz-Nawrocki, C.M. (1974) Effects of castration and testosterone replacement on the number of spermatozoa in the cauda epididymidis of hamsters. J. Reprod. Fert. 39, 97-100. 
Macmillan, E.W. \& Aukland, J. (1960) The transport of radio-opaque medium through the initial segment of the rat epididymis. J. Reprod. Fert. 1, 139-145.

Main, S. J., Davies, R.V. \& Setchell, B.P. (1978) Feedback control by the testis of gonadotrophin secretion: an examination of the inhibin hypothesis. $J$. Endocr. 79, 255-270.

Markkula-Viitanen, M., Nikkanen, V. \& Talo, A. (1979) Electrical activity and intraluminal pressure of the cauda epididymidis of the rat. J. Reprod. Fert. 57, 431-435.

Meistrich, M.L., Hughes, T.J. \& Bruce, W.R. (1975) Alteration of epididymal sperm transport and maturation in mice by oestrogen and testosterone. Nature, Lond. 258, 145-147.

Orgebin-Crist, M.C. (1962) Recherches experimentales sur la duree de passage des spermatozoides dans l'epididyme du Taureau. Annls Biol. anim. Biochim. Biophys. 2, 51-108.

Orgebin-Crist, M.C. (1965) Passage of spermatozoa labelled with thymidine- ${ }^{3} \mathrm{H}$ through the ductus epididymis of the rabbit. J. Reprod. Fert. 10, 241-251.

Orgebin-Crist, M.C., Danzo, B.J. \& Davies, J. (1975) Endocrine control of the development and maintenance of sperm fertilizing ability in the epididymis. In Handbook of Physiology, Section 7: Endocrinology,
Vol 5: Male Reproductive System, pp. 319-338. Eds D. W. Hamilton \& R. O. Greep, American Physiological Soc., Washington, D.C.

Pholpramool, C., White, R. W. \& Setchell, B.P. (1982) Influence of androgens in inositol secretion and sperm transport in the epididymis of rats. J. Reprod. Fert. 66, 547-553.

Pholpramool, C., Triphrom, N. \& Din-Udom, A. (1984) Intraluminal pressures in the seminiferous tubules and in different regions of the epididymis in the rat. J. Reprod. Fert. 71, 173-179.

Prins, G.S. \& Zaneveld, L.J.D. (1980) Radiographic study of fluid transport in the rabbit vas deferens during sexual rest and after sexual activity. J. Reprod. Fert. 58, 311-319.

Risley, P.L. (1963) Physiology of the male accessory organs. In Mechanism Concerned With Conception, pp. 73-133. Ed. C. G. Hartmann. MacMillan, New York.

Robb, G.W., Amann, R.P. \& Killian, G.J. (1978) Daily sperm production and epididymal sperm reserves of pubertal and adult rats. J. Reprod. Fert. 54, 103-107.

Wong, P.Y.D., Au, C.L. \& Ngai, N.K. (1978) Electrolyte and water transport in rat epididymis; its possible roie in sperm maturation. Int. J. Androl., Suppl. 2, $608-627$. 